\title{
DESA PENGALANGAN MENUJU SISTEM ECOFARMING INTEGRATED BERBASIS ORGANIK
}

\author{
Faisol Humaidi ${ }^{1}$, Aminatuzzuhro ${ }^{2}$, Linda Kurnia Hadi Putra ${ }^{3}$ \\ ${ }^{1,2,3}$ Universitas Wijaya Putra \\ faisolhumaidi@uwp.ac.id, aminatuzzuhro@uwp.ac.id, lindakurnia@uwp.ac.id
}

\begin{abstract}
Abstrak
Tujuan khusus dari Program Pengabdian Desa Pengalangan menuju sistem Ecofarming Integrated berbasis organik adalah; (1) Menjadikan desa Pengalangan Kecamatan Menganti Gresik Jawa Timur menjadi sentra Ecofarming Integrated berbasis Organik dengan produk hortikultura. (2) Aplikasi hasil riset unggulan perguruan tinggi yang sesuai dengan urgensi kebutuhan masyarakat; (3) Memberikan pendampingan masyarakat melalui pembuatan pupuk organik padat maupun cair, pestisida organik; (4) Menjadikan desa Pengalangan sebagai Sentra SayurOrganik.

Metode yang diterapkan adalah Ecofarming Integrated berbasis Organik dengan optimalisasi potensi dari limbah peternakan yang diolah untuk pupuk organik bagi tanaman sayuran dan padi. Serta penyediaan pakan ternak dari limbah jerami yang yang melimpah untuk pakan ternak dengan silase.

Hasil kegiatan tahun 2018 produksi kotoran sapi menjadi pupuk kandang rata-rata 2500 kg sampai dengan 3000 $\mathrm{kg} \mathrm{kg}$ per 21 hari. Sedangkan untuk urine sapi menjadi pupuk pelengkap cair (PPC) dalam kurun waktu untuk 1 peternak dengan populasi sapi 11 ekor telah menghasilkan produk PPC 200 liter siap pakai per bulan. Harga per $1 \mathrm{~kg}$ pupuk kandang masak sebesar Rp 350. Sedangkan 1 liter PPC curah seharga Rp.5.000. Rata-rata peternak 1 kali membuat $3000 \mathrm{~kg}$ menghasilkan pendapatan kotor sebesar Rp.1.050.000. sedangkan PPC rata-rata laku sebesar 100 liter dengan pendapatan kotor sebesar Rp. Rp.500.000.
\end{abstract}

Kata Kunci : Ecofarming Integrated, pupuk organik, Sentra Produk Organik 


\section{PENDAHULUAN}

Desa Pengalangan merupakan salah satu desa yang terletak di wilayah Kecamatan Menganti Kabupaten Gresik, dengan luas wilayah keseluruhan $4.818 \mathrm{Ha}$. Secara administratif Batas wilayah Desa Pengalangan sebagai berikut, Sebelah utara berbatasan dengan Kelurahan Pakal Kota Surabaya, sebelah timur : berbatasan dengan Kelurahan Made kota Surabaya. Sebelah selatan berbatasan dengan Desa Setro Kecamatan Menganti, sebelah barat berbatasan dengan Desa Randupadangan dan Desa Gempol kurung Kecamatan Menganti. Berjarak kurang lebih $3 \mathrm{~km}$ dari Universitas Wijaya Putra yang bisa ditempuh dengan waktu 8 menit sampai di desa Pengalangan Kecamatan Menganti Gresik. Ketinggian rata-rata Desa Pengalangan adalah $4 \mathrm{~m}$ dari permukaan air laut. Secara keseluruhan Desa pengalangan terdiri dari 8 RW, dan terbagi menjadi enam dusun. Dusun Bongso Kulon terdiri dari 1 RW, dusun Songgat terdiri dari $1 \mathrm{RW}$, dusun Pengalangan terdiri dari $2 \mathrm{RW}$, dusun Sumur Geger terdiri dari 1 RW, dusun Dukuh terdiri dari 1 RW, dan dusun Bongso Wetan terdiri dari 3 RW.

Salah satu problematika pertanian yang sering muncul didesa Pengalangan kecamatan Menganti Gresik adalah rendahnya produktifitas hortikultura dan pangan dan terus menurun dari tahun ke tahun. Pada musim tanam 2015-2016 sampai dengan musim tanam 2017 dengan rata-rata areal pertanaman sayur 175 Ha nampak adanya peenurunan produktifitas panenan sebesar $40-55 \%$ yang diakibatkan dari menurunnya kesuburan tanah akibat penggunaan pupuk kimia yang belebihan, musim yang sulit diprediksi, serta serangan organisme pengganggu tanaman/OPT semakin menjadi-jadi. Dari data dinas Pertanian Kabupaten Gresik 2016, desa Pengalangan sudah banyak serangan kompleks hama pada tamanan hortikultura terutama pada terong, pare, kanggkung dan cabe merah besar sedangkan pada tanaman padi terjadi serangan hebat wereng coklat. Adapun hama-hama yang sering menyerang, ulat Prodenia litura, L, kutu Aphis, Trips, Pseudococus citri, dan Nilaparvata lugens.

Peran dari Universitas Wijaya Putra dengan memberikan pendampingan pembuatan kompos dari kotoran sapi yang dulunya memakan waktu sekitar 2 bulan menjadi pupuk organik dengan kurun waktu 21 hari siap pakai untuk aplikasi pada tanaman budidaya. Potensi pupuk kandang/kompos siap pakai per $\mathrm{kg}$ sebesar Rp.350.- Potensi pengolahan kotoran sapi menjadi kompos inilah belum termanfaatkan dengan baik sebai peluang usaha bagi peternak sapi. Disamping itu urine sapi juga dijadikan pupuk organik cair dengan nilai komersial curah per liter sebesar Rp. 5.000.-

Produktifitas urine sapi yang dihasilkan di Desa Pengalangan Kecamatan Menganti Gresik juga cukup besar, rata-rata satu ekor sapi mengeluarkan urine berkisar 20 liter maka per hari dengan 102 ekor dihasilkan urine sapi sebannyak 2040 liter per hari dan sebagian besar masih belum mengerti arti dan manfaat urine sapi bagi pertanian. Harga pupuk organik cair dari urine sapi per liter di pasaran Surabaya dan Gresik berkisar Rp.5.000.-. Permintaan pupuk cair tersebut semakin hari semakin meningkat terutama diawal musim hujan karena petani padi dan hortikultura mulai tanam. Peternak sapi Desa Pengalangan Kecamatan Menganti Gresik masih belum mengerti bagaimana cara mengolah urine sapi menjadi pupuk organik cair.

Dari problema inilah Universitas Wijaya Putra Surabaya terutana Fakultas Pertanian UWP berusaha mengembangkan paket teknologi Ecofarming Integrated dalam pembuatan pupuk organik padat maupun pupuk organik cair urine sapi, fermentasi pakan ternak beserta programprogram pendampingan dalam peningkatan produktivitas pupuk organik kepada mitra Kelompok tani ternak 'Rojo Koyo II' Desa Pengalangan Kecamatan Menganti Gresik. Sedangkan bagi mitra kelompok petani Pengalangan dengan membuat kompos dari jerami padi beserta pestisida organik/botanical pesticide guna meningkatkan produktifitas budidaya sayuran dan lain-lain.

Integrated Ecofarming merupakan sistem pertanian terpadu yang bertumpu pada upaya-upaya untuk melindungi dan melestarikan alam dengan memanfaatkan bahan limbah organik sebagai media pertanian yang efektif dan efisien. Melalui siklus 
berterusan (sustainable cycle), disamping menghasilkan proses dan produk pertanian yang berkualitas dan sangat ekonomis sehingga petani turut tersejahterakan, sistem ini utamanya berguna untuk menjaga serta melestarikan lingkungan. Sistem ini akan signifikan dampak positifnya dan memenuhi kriteria pembangunan pertanian berkelanjutan karena berbasis organik dan dikembangkan/diarahkan berbasispotensi lokal (sumberdaya lokal). Tujuan penerapan sistem tersebut yaitu untuk menekan seminimal mungkin input dari luar (input/masukan rendah) sehingga dampak negatif sebagaimana disebutkan di atas, semaksimal mungkin dapat dihindari dan berkelanjutan (Nurcholis $\mathrm{M}$, G.Supangkat, 2011).

\section{METODE}

Metode pelaksanaan yang diterapkan di desa Pengalangan menggunakan metode PACA (Participatory Appraisal Competitive Advantage) dengan teknik assesment permasalahan dengan kombinasikan Top Down dan Bottom Up, sehingga prioritas program dan solusi yang ditawarkan merupakan hasil kesepakatan tim pengusul dengan mitra ini merupakan hasil kesepakatan antara tim Pengusul yang diwakili oleh ketua tim (Faisol Humaidi) dengan Desa Binaan yang diwakili oleh kepala desa Pengalangan Kecamatan Menganti Gresik, (Akhyar Abdul Mutholib), kelompok mitra binaan yang diwakili oleh ketua Gabungan Kelompok Tani Pengalangan (Yuswandi), ketua kelompok tani/ternak Rojo Koyo II (Twin Suryanto), dan Ketua Poktan Dusun Bongso Wetan Desa Pengalangan (Eko Santoso).

Secara skematis, uraian pola penyelesaian masalah disusun berdasarkan urgensi permasalahan yang bisa dilihat pada Tabel 2.1 dibawah ini.

Tabel 2.1 Uraian Pola Penyelesaian Masalah Desa Pengalangan

\begin{tabular}{|c|l|l|l|}
\hline $\begin{array}{c}\text { N } \\
\text { o }\end{array}$ & \multicolumn{1}{|c|}{2018} & \multicolumn{1}{|c|}{2019} & 2020 \\
\hline 1 & $\begin{array}{l}\text { Pendamping } \\
\text { an dalam } \\
\text { pembuatan } \\
\text { pupuk } \\
\text { organik }\end{array}$ & $\begin{array}{l}\text { Pembuatan } \\
\text { pupuk organik } \\
\text { padat dari } \\
\text { jerami padi }\end{array}$ & $\begin{array}{l}\text { Demplot } \\
\text { dan } \\
\text { penggunaan } \\
\text { produk } \\
\text { organik }\end{array}$ \\
\hline
\end{tabular}

\begin{tabular}{|c|c|c|c|}
\hline & $\begin{array}{l}\text { padat dari } \\
\text { kotoran sapi }\end{array}$ & & $\begin{array}{l}\text { pada } \\
\text { tanaman } \\
\text { sayuran } \\
\text { sebanyak } \\
90 \%\end{array}$ \\
\hline 2 & $\begin{array}{l}\text { Pendamping } \\
\text { an dalam } \\
\text { pembuatan } \\
\text { pupuk } \\
\text { organik cair } \\
\text { dari urine } \\
\text { sapi }\end{array}$ & $\begin{array}{l}\text { Pembuatan } \\
\text { pestisida } \\
\text { organik/botani } \\
\text { cal insectiside }\end{array}$ & $\begin{array}{l}\text { Penguatan } \\
\text { kelembagaa } \\
\text { n kelompok } \\
\text { tani/ternak }\end{array}$ \\
\hline 3 & $\begin{array}{l}\text { Pendamping } \\
\text { an dalam } \\
\text { pembuatan } \\
\text { pakan ternak } \\
\text { dari jerami } \\
\text { padi/silase }\end{array}$ & $\begin{array}{l}\text { Demplot dan } \\
\text { penguunaan } \\
\text { pupuk organik } \\
\text { padat/cair dan } \\
\text { pestisida } \\
\text { organik pada } \\
\text { lahan mitra } 1 \\
\text { dan } 2 \text { serta } \\
\text { sebagian lahan } \\
\text { kelompok tani }\end{array}$ & $\begin{array}{l}\text { Pendiran } \\
\text { badan } \\
\text { usaha/CV } \\
\text { dan HAKI }\end{array}$ \\
\hline 4 & $\begin{array}{l}\text { Demplot } \\
\text { penggunaan } \\
\text { pupuk } \\
\text { organik } \\
\text { padat dan } \\
\text { cair pada } \\
\text { tanaman } \\
\text { sayuran di } \\
\text { lahan mitra } \\
\end{array}$ & $\begin{array}{l}\text { Penanganan } \\
\text { pasca panen } \\
\text { sayur organik } \\
\text { dan uji coba } \\
\text { pemasaan }\end{array}$ & $\begin{array}{l}\text { Komersialis } \\
\text { asi produk } \\
\text { organik } \\
\text { secara } \\
\text { langsung } \\
\text { dan online }\end{array}$ \\
\hline 5 & & & $\begin{array}{l}\text { Sentra } \\
\text { Organik } \\
\text { Farming }\end{array}$ \\
\hline
\end{tabular}

Pada tahun pelaksanaan ke 1 (2018) kegiatan pengabdian Desa Pengalangan difokuskan pada pengangan limbah kotoran sapi yang mengganggu masyarakat menjadi produk pupuk kompos padat dan pupuk organik cair dari urine sapi untuk pertanaman sayuran yang berada di desa Pengalangan Kecamatan Menganti Gresik. Disamping itu juga adanya pendampingan pembuatan pakan ternak dari jerami padi/silase. Untuk usulan tahun ke 2 (2019) kegiatan difokuskan pada pembuatan pupuk organik padat dari jerami padi, pembuatan pestisida organik serta demplot pada tanaman sayuran yang dilakukan mitra dan sebagian dari kelompok desa Pengalangan. Sedangkan usulan pengabdian tahun ke 3(2020) difokuskan pada demplot yang meluas penggunaan pupuk organik padat dan cair, pestisida organik, penguatan kelompok tani/ternak, pendirian badan usaha berupa cv, haki brand merk, serta 
komersialisasi produk organik dengan pemasalan langsung online sehingga desa Pengalangan kecamatan Menganti Gresik menjadi sentra organik farming.

Introduksi sains dan iptek yang akan diterapkan oleh Universitas Wijaya Putra setiap tahunnya pada kegiatan ini disesuaikan dengan urutan prioritas permasalahan dan disusun dengan seksama supaya dapat melibatkan semua mitra pengabdian. Introduksi sains dan iptek bisa dilihat pada Tabel 2.2 dibawah ini :

Tabel 2.2 Introduksi sains dan iptek yang akan diterapkan oleh team Universitas Wijaya Putra

\begin{tabular}{|c|c|c|}
\hline No & $\begin{array}{c}\text { Aktifitas } \\
\text { Utama }\end{array}$ & Uraian Aktifitas \\
\hline 1 & $\begin{array}{l}\text { Pembuatan } \\
\text { Pupuk } \\
\text { Organik } \\
\text { Padat dari } \\
\text { Kotoran sapi }\end{array}$ & $\begin{array}{l}\text { - Kotoran sapi } \\
\text { disiapkan dan dibuat guludan } \\
\text { sesuai dengan tempat dan } \\
\text { kebutuhan } \\
\text { - Aplikasi media } \\
\text { bakteri pengurai yang telah } \\
\text { disediakan oleh pihak } \\
\text { Univesitas Wijaya Putra ke } \\
\text { guludan kotoran sapi tersebut } \\
\text { dan ditutup dengan plastik } \\
\text { untuk mngurangi penguapan. } \\
\text { - Setiap } 3 \text { hari dicek } \\
\text { dan dibolak balik guludan } \\
\text { kotoran sapi tersebut jika } \\
\text { kurang air perlu diberi air } \\
\text { secukupnya. } \\
\text { - Setelah } 21 \text { hari } \\
\text { kotoran sapi tersebut sudah } \\
\text { masak dan siap dipackaging } \\
\text { dan siap diaplikasikan pada } \\
\text { lahan pertanian }\end{array}$ \\
\hline 2 & $\begin{array}{l}\text { Pembuatan } \\
\text { Pupuk } \\
\text { Organik } \\
\text { Cair dari } \\
\text { Urine Sapi }\end{array}$ & $\begin{array}{l}\text { - Menampung urine } \\
\text { sapi dalam bak penampungan } \\
\text { besar } \\
\text { - } \quad \text { Setelah penuh urine } \\
\text { sapi dalam tampungan } \\
\text { diaplikasikan bakteri } \\
\text { pengurai yang } \\
\text { menguntungkan dan telah } \\
\text { disiapkan pihak Universitas } \\
\text { Wijaya Putra } \\
\text { - } \quad \text { Bak penampungan } \\
\text { ditutup kain kasa dan } \\
\text { diinkubasi selama } 21 \text { hari. } \\
\text { - } \quad \text { Setelah } 21 \text { hari siap } \\
\text { disaring dan dimasukkan } \\
\text { kesdalam kemasan } 1 \text { liter. }\end{array}$ \\
\hline
\end{tabular}

\begin{tabular}{|c|c|c|}
\hline & & $\begin{array}{l}\text { - Siap diplikasikan } \\
\text { pada tanaman sayuran } \\
\text { organik. }\end{array}$ \\
\hline 3 & $\begin{array}{l}\text { Pembuatan } \\
\text { Pupuk } \\
\text { Organik } \\
\text { Padat dari } \\
\text { jerami Padi }\end{array}$ & $\begin{array}{l}\text { - Jerami padi } \\
\text { disiapkan dan dipotong- } \\
\text { potong dengan mesin } \\
\text { pencacah. } \\
\text { - Hasil pencacahan } \\
\text { jerami di Aplikasi media } \\
\text { bakteri pengurai yang telah } \\
\text { disediakan oleh pihak } \\
\text { Univesitas Wijaya Putra ke } \\
\text { guludan jerami padi tersebut } \\
\text { dan ditutup dengan plastik } \\
\text { untuk mngurangi penguapan. } \\
\text { - Setiap } 3 \text { hari dicek } \\
\text { dan dibolak balik guludan } \\
\text { kotoran sapi tersebut jika } \\
\text { kurang air perlu diberi air } \\
\text { secukupnya. } \\
\text { - Setelah 21 hari } \\
\text { jerami padi tersebut sudah } \\
\text { masak dan siap dipackaging } \\
\text { dan siap diaplikasikan pada } \\
\text { lahan pertanian }\end{array}$ \\
\hline 4 & $\begin{array}{l}\text { Pembuatan } \\
\text { Pestisida } \\
\text { Organik }\end{array}$ & $\begin{array}{l}\text { - Menyiapkan daun } \\
\text { mimba (Azadiracta indica. L) } \\
\text { sebanyak } 200 \text { gram digerus } \\
\text { dan larutkan kedalam air } \\
\text { sampai mendekati } 2 \text { liter air. } \\
\text { - } \quad \text { Inkubasi selama 3-5 } \\
\text { hari setelah itu disaring dan } \\
\text { dimasukkan dalam } \\
\text { kemasan/kaleng plastik. } \\
\text { - Pestisida organik } \\
\text { tersebut siap diaplikasikan ke } \\
\text { pertanaman sayuran }\end{array}$ \\
\hline
\end{tabular}

\section{HASIL DAN PEMBAHASAN}

\section{Produktifitas Pupuk Kandang Sapi}

Hasil kegiatan pada program ke 1 dengan produktifitas kotoran sapi menjadi pupuk kandang meningkat pesat dengan rata-rata $2500 \mathrm{~kg}$ sampai dengan $3000 \mathrm{~kg} \mathrm{~kg}$ per 21 hari fermentasi pupuk kandang basah dengan menggunakan bakteri pengurai dari pengembangan riset team pengabdi Universitas Wijaya Putra. Rata-rata peternak 1 kali membuat $3000 \mathrm{~kg}$ menghasilkan pendapatan kotor sebesar Rp.1.050.000.dengan harga per $1 \mathrm{~kg}$ sebesar $\mathrm{Rp}$ 350.-. 
Dalam kurun waktu rata-rata setiap peternak sapi Rojo Koyo II mendapatkan rata-rata pendatan selama 10 bulan sebesar Rp. 9.782.500.- Penjualan Pupuk kandang sapi tersebut terserap di Gabungan Kelompok Tani Pengalangan yang diketuai oleh Yuswandi. Para Peternak sapi Rojo Koyo II (mitra 2) dapat meningkatkan pendapatan usaha taninya dari pengolahan pupuk kandang basah menjadi pupuk kandang siap pakai dimana sebelumnya menjadi limbah yang dibuang bersamaan dengan urine sapi ke drainase depan rumahrumah petani dan penduduk.

Tabel 3.2 Produktifitas Pupuk Kandang Siap Pakai per Peternak Sapi tahun 2018

\begin{tabular}{|l|l|l|l|}
\hline No & Bulan ke & $\begin{array}{l}\text { Pupuk } \\
\text { Kandang } \\
(\mathrm{Kg})\end{array}$ & $\begin{array}{l}\text { Pendapatan } \\
\text { Rata-rata } \\
(\mathrm{Rp})\end{array}$ \\
\hline 1 & Maret & 2500 & 875.000 \\
\hline 2 & April & 2500 & 875.000 \\
\hline 3 & Mei & 2600 & 910.000 \\
\hline 4 & Juni & 2650 & 927.500 \\
\hline 5 & Juli & 2700 & 945.000 \\
\hline 6 & Agustus & 3000 & 1.050 .000 \\
\hline 7 & September & 3000 & 1.050 .000 \\
\hline 8 & Oktober & 3000 & 1.050 .000 \\
\hline 9 & Nopember & 3000 & 1.050 .000 \\
\hline 10 & Desember & 3000 & 1.050 .000 \\
\hline & Jumlah & 27.950 & 9.782 .500 \\
\hline
\end{tabular}

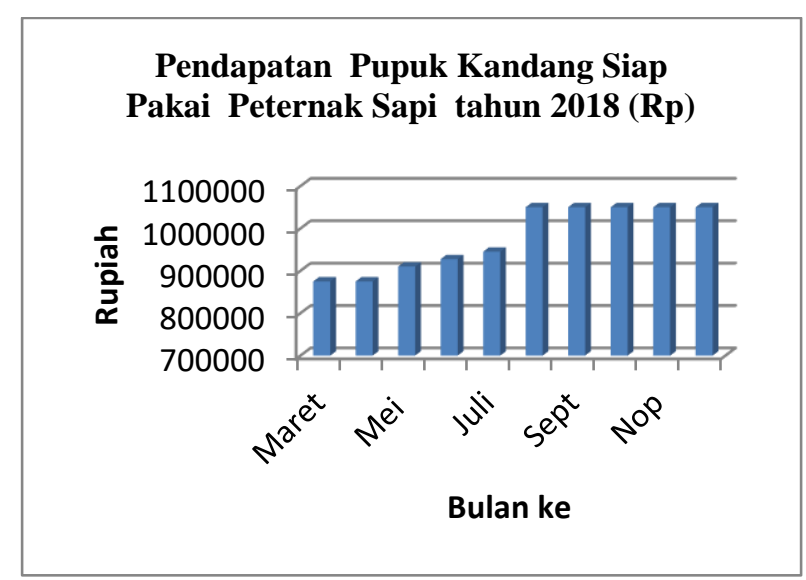

Gambar 3.1 Pendapatan produk Pupuk kandang siap pakai Peternak Sapi 2018

\section{Produktifitas PPC Organik}

Produktifitas untuk urine sapi menjadi pupuk pelengkap cair (PPC) dalam kurun waktu untuk 1 peternak dengan populasi sapi rata-rata 11 ekor telah menghasilkan produk PPC 200 liter siap pakai per bulan. Sedangkan 1 liter PPC curah seharga Rp.5.000. sedangkan PPC rata-rata laku sebesar 100 liter dengan pendapatan kotor sebesar Rp. Rp.500.000.Sedangkan dalam bentuk kemasan botol plastik ukuran 1 liter dijual seharga $\mathrm{Rp}$. 12.500.- Sebagian besar Gabungan Kelompok Tani Pengalangan memanfaatkan urine sapi dalam pertanaman sayur organik seperti Terong, kangkung, kacang panjang dan cabe.

Tabel 3.2 Produktifitas Urine Sapi per Peternak Sapi tahun 2018

\begin{tabular}{|l|l|l|l|}
\hline No & Bulan ke & $\begin{array}{l}\text { PPC } \\
\text { Organik } \\
(\text { Liter })\end{array}$ & $\begin{array}{l}\text { Pendapatan } \\
\text { Rata-rata } \\
(\mathrm{Rp})\end{array}$ \\
\hline 1 & Maret & 150 & 750.000 \\
\hline 2 & April & 200 & 1.000 .000 \\
\hline 3 & Mei & 200 & 1.000 .000 \\
\hline 4 & Juni & 200 & 1.000 .000 \\
\hline 5 & Juli & 200 & 1.000 .000 \\
\hline 6 & Agustus & 200 & 1.000 .000 \\
\hline 7 & September & 200 & 1.000 .000 \\
\hline 8 & Oktober & 200 & 1.000 .000 \\
\hline 9 & Nopember & 200 & 1.000 .000 \\
\hline 10 & Desember & 200 & 1.000 .000 \\
\hline & Jumlah & 1.950 & 9.750 .000 \\
\hline
\end{tabular}

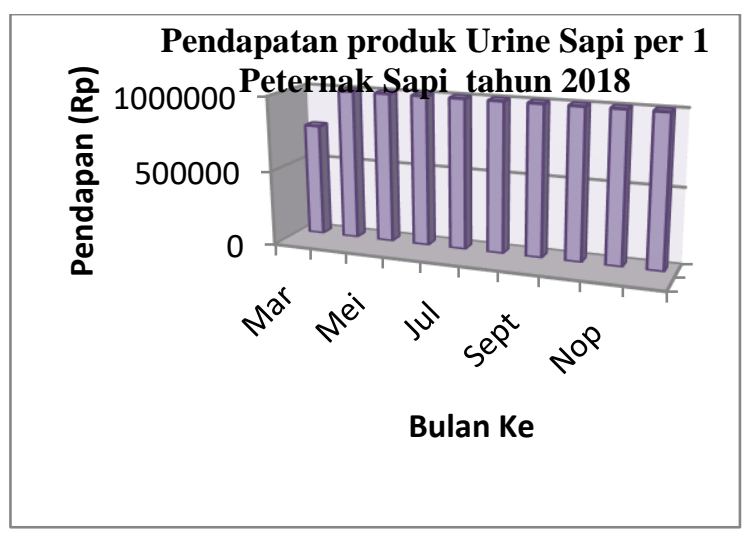

Gambar 3.1 Pendapatan produk Urine Sapi per Peternak Sapi tahun 2018

\section{Demplot Penggunaan Pupuk Kandang dan PPC Organik}

Dengan penggunaan pupuk kandang sapi masak dan PPC urine sapi yang dihasilkan dari kelompok peternak Rojo Koyo II desa Pengalangan Kecamatan Menganti Gresik ternyata dapat menurunkan serangan organisme pengganggu tanaman/hama yang 
biasa menyerang pertanaman hortikultura dan padi seperti ulat Prodenia litura, L, kutu Aphis, Trips, Pseudococus citri, dan Nilaparvata lugens.Disamping itu tingkat dan kualitas panenan sayuran lebih tinggi sebelum menggunakan 2 produk tersebut.

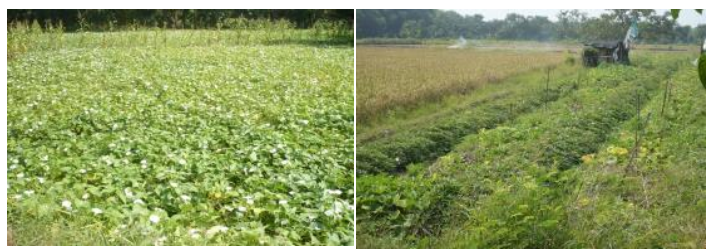

Gambar 3.2 Hamparan tanaman padi dan sayuran dengan penggunaan pupuk kandang sapi dan PPC Organik

Adapun perbandingan produktifitas panenan sebelum dan sesudah menggunakan pupuk kandang hasil fermentasi dan PPC Organik sebagai berikut :

Tabel 3.3 Perbandingan Produktifitas Hortikulturasebelum dan sesudah pemakaian Pupuk Kandang Sapi siap pakai dan PPC Organik.

\begin{tabular}{|l|l|l|l|}
\hline \multirow{2}{*}{ No } & \multirow{2}{*}{ Komoditi } & \multicolumn{2}{|c|}{ Produktivitas ton/Ha/tahun } \\
\cline { 3 - 4 } & & $\begin{array}{c}\text { Sebelum } \\
\text { Pemakaian }\end{array}$ & $\begin{array}{c}\text { Sesudah } \\
\text { Pemakaian }\end{array}$ \\
\cline { 3 - 4 } & & 2017 & 2018 \\
\hline 2 & Terong (35 ha) & 1.398 .600 & 1.450 .000 \\
\hline 3 & $\begin{array}{l}\text { Kacang } \\
\text { Panjang (30 } \\
\text { ha) }\end{array}$ & 799.200 & 800.500 \\
\hline 4 & Pare (25 ha) & 38.850 & 42.500 \\
\hline 5 & $\begin{array}{l}\text { Kangkung } \\
\text { (iket/thn) }(20\end{array}$ & 7.281 .600 & 8.050 .000 \\
\hline ha) & $\begin{array}{l}\text { Cabe merah } \\
\text { (45 ha) }\end{array}$ & 432.900 & 455.000 \\
\hline
\end{tabular}

Produk limbah dari petani sapi dan sebagian petani hortikultura/sayuran dimanfaatkan bagi peternak sapi dalam pemberian pakan. Khusus untuk limbah jerami diolah khusus menjadi silase yang berguna untuk pakan ternak. Silase tersebut telah difermentasi dengan menggunakan flokulan bakteri yang telah disediakan oleh team Universitas Wijaya Putra.

\section{KESIMPULAN}

Hasil kegiatan Pengabdian Masyarakat tahun
2018 yaitu :

1. Produktifitas kotoran sapi menjadi pupuk kandang siap pakai meningkat pesat dengan rata-rata 2500 $\mathrm{kg}$ sampai dengan $3000 \mathrm{~kg} \mathrm{~kg}$ per 21 hari fermentasi pupuk kandang basah.

2. Sedangkan untuk urine sapi menjadi pupuk pelengkap cair (PPC) dalam kurun waktu untuk 1 peternak dengan populasi sapi rata-rata 11 ekor telah menghasilkan produk PPC 200 liter siap pakai. Harga per $1 \mathrm{~kg}$ pupuk kandang masak sebesar Rp 350. Sedangkan 1 liter PPC curah seharga Rp.5.000.

3. Rata-rata peternak 1 kali membuat $3000 \mathrm{~kg}$ menghasilkan pendapatan kotor sebesar Rp.1.050.000.- sedangkan PPC ratarata laku sebesar 100 liter dengan pendapatan kotor sebesar Rp. Rp.500.000.- Sedangkan dalam bentuk kemasan botol plastik ukuran 1 liter dijual seharga Rp. 12.500.-

4. Dari sisi peternak yang mengikuti program pengabdian ini sebanyak 11 peternak dengan ujicoba awal di peternak Twin Suryanto. Setelah kegiatan ini berhasil maka peternak berlomba-lomba membuat paket teknologi pengolahan kotoran sapi dan urine menjadi pupuk organik padat dan cair. Sedangkan paket teknologi bakteri pengurai telah disediakan oleh pihak Fakultas Pertanian Universitas Wijaya Putra Surabaya

\section{REFERENSI}

Abdullah, A et.al (2015), Status Keberlanjutan Adopsi Teknologi Pengolahan Limbah Ternak sebagai Pupuk Organik, MIMBAR, Vol 31, (Juni 2015) : 1120

BPS Gresik (2015), Kecamatan Menganti Dalam Angka 2015, Badan Pusat Statistik Gresik, Katalog BPS : 1102001.3525040

Nurhidayati, e.al (2008), E-Book 
Pertanian Organik Suatu Kajian Sistem

Pertanian Terpadu dan Berkelanjutan, PROGRAM STUDI AGROTEKNOLOGI JURUSAN BUDIDAYA PERTANIAN FAKULTAS PERTANIAN UNIVERSITAS ISLAM MALANG, 196 Hal.

Nurcholis, M, G Supangkat (2011), Pengembangan Integrated Farming System Untuk Pengendalian Alih Fungsi Lahan Pertanian, Prosiding Seminar Nasional Budidaya Pertanian, Urgensi dan Strategi Pengendalian Alih Fungsi Lahan Pertanian , Bengkulu 7 Juli 2011, ISBN 978 602-19247-0-9

Sirajuddin, SN, S.Rohani,I.Rasyid ${ }^{1)}$ (2011), Proses Adopsi Pembuatan Pupuk Cair Dari Urine Sapi Oleh Kelompok Ternak Sapi Potong di Kabupaten Sinjai, Propinsi Sulawesi Selatan, ) Staf Pengajar Jurusan Sosial Ekonomi Peternakan FAPET, UNHAS. 